\title{
Comparative Assessment of the Environmental Dynamics of Dissolved Organic Nitrogen (DON) and Dissolved Organic Phosphorus (DOP) from Three Wetlands in Northern Nigeria
}

\author{
${ }^{* 1}$ S. Yusuf, ${ }^{1}$ A. A. Audu and 2 M. Wazir \\ 1Department of Pure and Industrial Chemistry, Bayero University, P. M. B. 3011, Kano, Nigeria \\ 2Department of Chemistry, Federal University, Gashua. \\ [Corresponding Author: E-mail: sayzay37@yahoo.com]
}

\section{ABSTRACT}

This study assessed comparatively the environmental dynamics of dissolved organic nitrogen (DON) and dissolved organic phosphorus (DOP) in water samples obtained from three locations (Lokoja, Jebba and Hadejia-Nguru) with five sampling sites in Northern Nigeria. These sites include Jebba, Matara-Uku, Lokoja, Baturiya and Nguru. Samples were collected during the dry and wet seasons of the year 2015 and levels of nitrogen and phosphorus determined using the persulphate wet-oxidation method. The average values for DON and DOP obtained ranged from $9.49 \pm 1.83 \mathrm{mg} / \mathrm{l}$ to $21.8 \pm 14.7$ $\mathrm{mg} / \mathrm{l}$ and $1.65 \pm 0.38 \mathrm{mg} / \mathrm{l}$ to $6.11 \pm 0.58 \mathrm{mg} / \mathrm{l}$ respectively. The values obtained for DON during the dry and wet seasons were Jebba (14.1 \pm 3.92$)$, Matara-Uku (13.7 \pm 3.43$)$, Lokoja (21.0 \pm 5.04$)$, Baturiya (21.8 \pm 14.7$)$, Nguru (7.14 \pm 2.40$)$ and Jebba (13.9 \pm 1.97$)$, Matara-Uku (11.3 \pm 2.62$)$, Lokoja $(9.59 \pm 1.46)$, Baturiya $(9.49 \pm 1.83)$, Nguru $(11.1 \pm 1.78) \mathrm{mg} / \mathrm{l}$ respectively. The mean values for DOP were Jebba (1.85 \pm 0.07$)$, Matara-Uku (2.60 \pm 0.55$)$, Lokoja (2.65 \pm 0.31$)$, Baturiya (2.52 \pm 0.46$)$, Nguru (1.65 \pm 0.38$)$

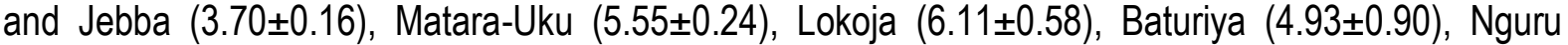
$(3.65 \pm 0.37) \mathrm{mg} / \mathrm{l}$ in the dry and wet seasons respectively. The DON concentrations were significantly higher $(p<0.05)$ in the dry season when compared with the wet season while the DOP concentrations were significantly higher $(p<0.05)$ in the wet season when compared with the dry season. This dynamics was attributed to run off from agricultural farm lands, hydrology and the rate of utilization of these nutrients by water plants. High concentrations of DOP and DON supportgood yield of agricultural produce of the farmlands around the wetlands.

Keywords: Dissolved organic nitrogen, dissolved organic phosphorus, dissolved organic matter, wetlands

\section{INTRODUCTION}

Wetlands are areas of marsh, fen, peat land or water whether natural or artificial, permanent or temporary, with water that is static or flowing, fresh brackish or salt, including areas of marine water the depth of which at low tide does not exceed 6 meters (Ramsar 1994). Wetlands form an important boundary between uplands and aquatic environments and are hydrologically linked by surface and/or subsurface flows (Mitsch and Gosselink, 1993). Hydrology and hydrochemical regimes are the major factors controlling wetland vegetation, composition and structure (Kennedy, 2001).

The dissolved reactive phosphorus (DRP) fraction is the most available form of phosphorusin aquatic ecosystems, there is growing interest in the transport, transformation and bioavailability of organic phosphorus. Phosphorus occurs in natural waters in both particulate and dissolved forms, and the dissolved fraction consist of compounds like inositol phosphates, nucleic acids, sugar phosphates and condensed phosphates and orthophosphates (Peat et al., 1997). The most frequently determined forms of dissolved phosphorus are DRP and total dissolved phosphorus (TDP).

Phosphorus can enter wetlands with suspended solids or as dissolved phosphorus with significant quantities associated with sediments (Walbridge and Struthers 1993). Phosphorus removal from water in wetlands occurs through use by plants and soil microbes; adsorption by aluminium and iron oxides and hydroxides; precipitation as 
aluminium, iron, and calcium phosphates; and burial as adsorbed or to sediments or organic matter (Johnston 1991; Walbridge and Struthers 1993).

Due to low mineral matter content and high organic matter content, a large proportion of phosphorus in wetlands is stored in organic forms (Reddy et al., 1999). Sources of such organic phosphorus in wetlands include herbicides, pesticides, fungicides, algae and runoff from farms.

Dissolved organic nitrogen (DON) is a complex mixture that is primarily composed of amino acids, amino sugars, amides, peptides and heterocyclic-N compounds (Leenheer, 2004). The primary sources of DON include agricultural fertilizers, wastewater discharges, forest litter, and excretion of algae products in eutrophic water (Westerhoff and Mash, 2002). In aerobic wetlands, organic nitrogen may mineralize to ammonium, which plants and microbes can utilize, adsorb to clay, or diffuse to the surface (Johnston, 1991).

Previous studies found that urban areas and agricultural farmlands contribute to DON and DOP concentrations (Harrison et al., 2005). This is due to the fact that wetlands are intensively cultivated with extensive use of nitrogen-based fertilizers and organophosphoric insecticides. Pittal et al. (2014) also reported that industrial activities, extensive use of nitrogen-based fertilisers and organophosphoric insecticides in the Evros basin resulted in water bodies being enriched with DON and DOP. Wastewater discharges and runoff from agricultural farmlands have been found to contain elevated concentrations of DON (Westerhoff and Mash 2002). The aim of the research was to determine the concentrations of DON and DOP in the water samples obtained from three wetlands in relation to changes in seasons as well as their geographical locations.

\section{The Study Area}

The Lokoja and Jebba wetlands (Figure 1) are part of the Lower Kaduna-Middle Niger wetlands which are located on the extensive floodplain of the mid-section of River Niger (in Nigeria) and the lower course of one of its main tributary, River Kaduna. The wetlands extend from Jebba $\left(9^{\circ} 00^{\prime} \mathrm{N} 4^{\circ} 50^{\prime} \mathrm{E}\right)$ to Baro $\left(8^{\circ} 35^{\prime} \mathrm{N}\right.$ $6^{\circ} 25^{\prime} \mathrm{E}$ ) along the Niger, and from Wuya Bridge on the River Kaduna, along the Jebba - Bida $\left(9^{\circ} 00^{\prime} \mathrm{N} 6^{\circ} 00^{\prime} \mathrm{E}\right)$ road downstream to Pategi $\left(8^{\circ} 45^{\prime} \mathrm{N} 5^{\circ} 37^{\prime} \mathrm{E}\right)$ on the south bank of the Niger.

The Hadejia-Nguru wetlands (Fig. 1) are located between latitudes $12^{\circ} 15^{\prime} \mathrm{N}$ and $12^{\circ} 55^{\prime} \mathrm{N}$, and between longitudes $10^{\circ} \mathrm{E}$ and $11^{\circ} \mathrm{E}$ in the sudan savanna of Nigeria and are designated as a Ramsar site by the Ramsar Convention; it is presently the only Ramsar site in Nigeria (Hollis et al., 1993). Baturiya wetland (Figure 1) occupies an estimated area of 3500 square kilometres and is located between latitude $12^{\circ} 31^{\prime} \mathrm{N}$ and longitudes $010^{\circ} 29^{\prime} \mathrm{E}$ (Hollis et al.,1993).In Jebba wetland samples were collected from sites $\mathrm{J} 1, \mathrm{~J} 2, \mathrm{~J} 3, \mathrm{~J} 4, \mathrm{~J} 5$, J6 and $\mathrm{J} 7$, in Matara-Uku wetland samples were collected from sites M1, M2, M3, M4, M5, M6 and $\mathrm{M7}$, while in Baturiya wetland sites BR1, $\mathrm{BR} 2, \mathrm{BR} 3, \mathrm{BR} 4, \mathrm{BR} 5, \mathrm{BR} 6$ and BR7 were sampled. Likewise, in Lokoja wetlands sites LA1, LA2, LA3, LA4, LA5, LA6 and LA7 were also sampled. Similarly, samples were also collected from sites N1, N2, N3, N4, N5, N6 and N7 in Nguru wetland.

\section{MATERIAL AND METHODS}

All chemicals were of analytical grade. Solutions were prepared using distilleddeionised water.

\section{Sampling and sample pre-treatment}

Samplings were carried out during the early part of the dry and the wet season of the year 2015.Water samples from the wetlands were collected in $500 \mathrm{~cm}^{3}$ white, low-density polyethylene bottles from 35 sites across five sampling locations spread $200 \mathrm{~m}$ apart. The water samples were collected by immersing the sample container nozzle down 0.5 meter and slowly allowing them to fill (APHA, 1992). All the samples were appropriately labelled and stored in a large plastic buckets with ice blocks. The water samples were then filtered using 0.7 $\mu \mathrm{m}$ GF/F grade filter and then stored in a refrigerator at $4{ }^{\circ} \mathrm{C}$. 
To $50 \mathrm{~cm}^{3}$ of the filtered water sample in a 125 $\mathrm{cm}^{3}$ Erlenmeyer flask $1 \mathrm{~cm}^{3}$ of $2.5 \mathrm{M} \mathrm{H}_{2} \mathrm{SO}_{4}$ solution and $25 \mathrm{~cm}^{3}$ of $0.185 \mathrm{M}$ alkaline persulphate solutions were added and boiled gently using a hot plate until a final volume of
$10 \mathrm{~cm}^{3}$ was attained. The resulting solution was allowed to cool then diluted to $30 \mathrm{~cm}^{3}$ with distilled water. A drop of phenolphthalein indicator solution was added and neutralized to a faint pink colour with $0.42 \mathrm{M} \mathrm{NaOH}$ solution.

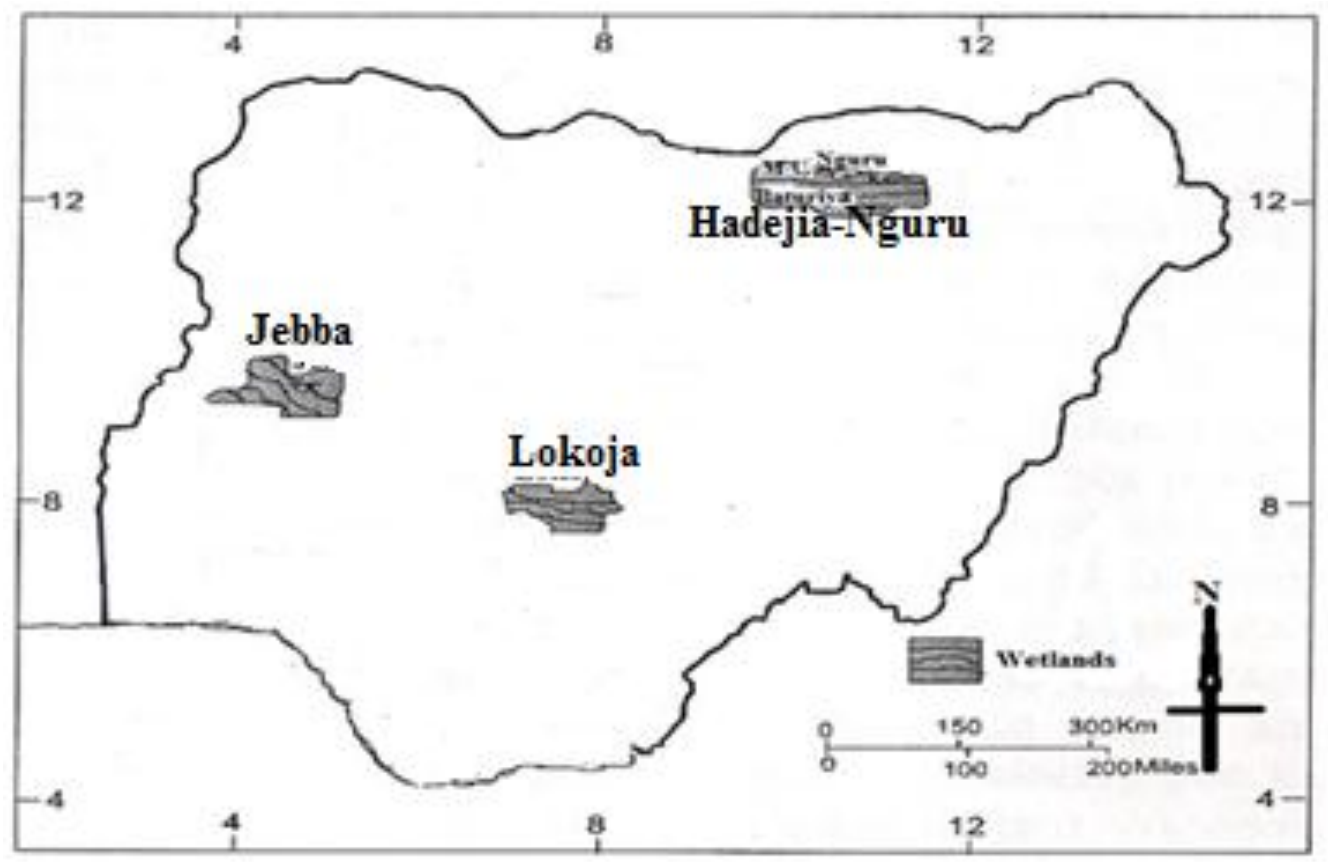

Figure 1: Location of Jebba, Lokoja Hadejia-Nguru Wetlands in Northern Nigeria

\section{Procedure for phosphorus determination}

Exactly $30 \mathrm{~cm}^{3}$ of the sample was pipetted into a $50 \mathrm{~cm}^{3}$ calibrated flask with the addition of 8 $\mathrm{cm}^{3}$ of the mixed reagent (which comprise 125 $\mathrm{cm}^{3}$ of $2.5 \mathrm{M}$ tetraoxosulphate (VI) acid, $37.5 \mathrm{~cm}^{3}$ of $0.0324 \mathrm{M}$ ammonium molybdate, 75 $\mathrm{cm}^{3}$ of $0.1 \mathrm{M}$ of ascorbic acid and $12.5 \mathrm{~cm}^{3}$ of $0.008214 \mathrm{M}$ potassium antimony tartrate solution) and mixed thoroughly (Johnes and Heathwaite,1992). The solution was allowed to stand for 20 minutes for optimum colour formation after which the absorbance of the sample was measured at $880 \mathrm{~nm}$ (using A755S UV-VIS spectrophotometer equipped with Deuterium Lamp and Halogen-Tungsten Lamp), using reagent blank as the reference solution (Charles et al. 2003). The total dissolved phosphorus was determined after persulphate digestion of the samples and the hydrolysable phosphorus was determined after digesting the samples using $5 \mathrm{M}$ tetraoxosulphate $(\mathrm{VI})$ acid. The concentrations of total dissolved phosphorus and hydrolysable phosphorus were extrapolated from the calibration curve. The Dissolved organic phosphorus (DOP) concentration was then calculated by subtracting the hydrolysable Phosphorus concentration from total dissolved phosphorus (TDP) concentration.

\section{Procedure for nitrogen determination}

To $50 \mathrm{~cm}^{3}$ of the filtered water sample in a 125 $\mathrm{cm}^{3}$ Erlenmeyer flask $1 \mathrm{~cm}^{3}$ of $2.5 \mathrm{M} \mathrm{H}_{2} \mathrm{SO}_{4}$ solution and $25 \mathrm{~cm}^{3}$ of $0.185 \mathrm{M}$ alkaline persulphate solutions were added and boiled gently using a hot plate until a final volume of $10 \mathrm{~cm}^{3}$ was attained. The resulting solution was allowed to cool then diluted to $30 \mathrm{~cm}^{3}$ with distilled water. A drop of phenolphthalein indicator solution was added and neutralized to a faint pink colour with $0.42 \mathrm{M} \mathrm{NaOH}$ solution. Five (5) $\mathrm{cm}^{3}$ of the digested sample was pipetted into a $50 \mathrm{~cm}^{3}$ volumetric flask and $10 \mathrm{~cm}^{3}$ of $0.5 \mathrm{M} \mathrm{NaOH}$ solution and $10 \mathrm{~cm}^{3}$ of the reducing reagent $\left(0.0169 \mathrm{~mol} / \mathrm{dm}^{3}\right.$ of hydrazine sulphate, 0.016 moldm $^{-3}$ of copper sulphate pentahydrate and $0.0619 \mathrm{~mol} / \mathrm{dm}^{3}$ zinc sulphate), (Johnes et al., 1992), were 
added and heated for 15 minutes at $52^{\circ} \mathrm{C}$. Afterwards, $10 \mathrm{~cm}^{3}$ of $0.0581 \mathrm{M}$ acidic sulphanilamide solution was added, shaken thoroughly for 5 minutes for the diazotization reaction to go to completion. Finally, $10 \mathrm{~cm}^{3}$

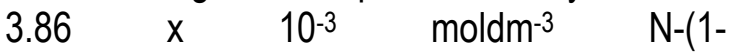
Naphthyl)ethylenediamine dihydrochloride solution was added to form an azo dye and the contents diluted to $50 \mathrm{~cm}^{3}$ with water. The absorbance of the pink coloured dye solution was measured at $540 \mathrm{~nm}$ against the corresponding reagent blank (Johnes and Heathwaite, 1992). The total nitrogen was determined after the persulphate digestion as described above, while the $\mathrm{NO}_{3}{ }^{-}$and $\mathrm{NO}_{2}{ }^{-}$), were determined following the procedure above without the persulphate digestion, whereas $\mathrm{NH}_{4}{ }^{+}$was measured colorimetrically by the indophenol method as described below. DON was then calculated by subtracting the sum of the inorganic nitrogen species $\left(\mathrm{NO}_{3}{ }^{-}, \mathrm{NO}_{2}{ }^{-}\right.$and $\mathrm{NH}_{4}^{+}$) from total dissolved nitrogen (TDN).

\section{Procedure for $\mathrm{NH}_{4}{ }^{+}-\mathrm{N}$ Determination (indophenol method)}

To $25 \mathrm{~cm}^{3}$ of the sample in $50 \mathrm{~cm}^{3}$ Erlenmeyer flask was added $1 \mathrm{~cm}^{3}$ phenol solution, $1 \mathrm{~cm}^{3}$ sodium nitroprusside solution and 2.5 $\mathrm{cm}^{3}$ oxidising solution $\left(0.34 \mathrm{moldm}^{-3}\right.$ alkaline trisodium citrate and sodium hypochlorite), (Nikolaos, et al., 2010). the resulting solution was thoroughly mixed after each addition. The samples were covered with plastic wrap and kept in the dark at ambient temperature for $1 \mathrm{~h}$ (Nikolaos et al., 2010).The absorbance was measured at $640 \mathrm{~nm}$ against the reagent blank.

\section{Data Analysis}

All analyses were performed in triplicates and the results expressed as mean $\pm S D$. The SPSS veersion20.0software was used for the analysis. The difference in DON and DOP concentrations among the different sites were tested by analysis of variance method, (ANOVA) and Tukey's test was used to determine pair wise differences among locations. A value of $p<0.05$ was considered statistically significant.

\section{RESULTS AND DISCUSSION}

Table 1 shows DOP concentrations in wetland ponds during the wet season of 2015. The concentrations determined were in the range of $3.19 \pm 0.022-6.54 \pm 0.13 \mathrm{mg} / \mathrm{l}$. Highest level was observed at site LA5 in lokoja $(6.54 \pm 0.13 \mathrm{mg} / \mathrm{L})$ while the lowest value was recorded at site N5 in Nguru wetland during the wet season.

Table 1: Mean Concentration of DOP in Jebba, Baturiya, Lokoja, Matara-Uku and Nguru wetlands during the Wet Season of 2015

\begin{tabular}{llllll}
\hline site & Concentration $(\mathrm{mg} / \mathrm{l})$ & site & Concentration $(\mathrm{mg} / \mathrm{l})$ & site & Concentration $(\mathrm{mg} / \mathrm{l})$ \\
\hline $\mathrm{J} 1$ & $3.70 \pm 0.21$ & LA1 & $6.54 \pm 0.13$ & $\mathrm{~N} 1$ & $3.44 \pm 0.02$ \\
$\mathrm{~J} 2$ & $3.66 \pm 0.11$ & LA2 & $6.41 \pm 0.11$ & $\mathrm{~N} 2$ & $3.55 \pm 0.02$ \\
$\mathrm{~J} 3$ & $3.89 \pm 0.09$ & LA3 & $6.52 \pm 0.21$ & $\mathrm{~N} 3$ & $3.71 \pm 0.023$ \\
$\mathrm{~J} 4$ & $3.47 \pm 0.10$ & LA4 & $6.50 \pm 0.11$ & $\mathrm{~N} 4$ & $3.69 \pm 0.012$ \\
$\mathrm{~J} 5$ & $3.57 \pm 0.12$ & LA5 & $6.24 \pm 0.12$ & $\mathrm{~N} 5$ & $3.19 \pm 0.022$ \\
$\mathrm{~J} 6$ & $3.68 \pm 0.13$ & LA6 & $5.34 \pm 0.11$ & $\mathrm{~N} 6$ & $4.40 \pm 0.022$ \\
$\mathrm{~J} 7$ & $3.91 \pm 0.10$ & LA7 & $5.22 \pm 0.09$ & $\mathrm{~N} 7$ & $3.57 \pm 0.087$ \\
BR1 & $5.53 \pm 0.09$ & M1 & $5.68 \pm 0.08$ & & \\
BR2 & $5.16 \pm 0.01$ & M2 & $5.22 \pm 0.10$ & & \\
BR3 & $5.51 \pm 0.31$ & M3 & $5.74 \pm 0.21$ & & \\
BR4 & $3.42 \pm 0.12$ & M4 & $5.43 \pm 0.22$ & & \\
BR5 & $5.55 \pm 0.22$ & M5 & $5.71 \pm 0.23$ & & \\
BR6 & $3.69 \pm 0.11$ & M6 & $5.81 \pm 0.12$ & & \\
BR7 & $5.63 \pm 0.09$ & M7 & $5.25 \pm 0.11$ & & \\
\hline
\end{tabular}


Nigerian Journal of Basic and Applied Science (December, 2017), 25(2): 151-162

Table 2: Analyses of variance for dissolved organic nitrogen (DON) and phosphorus (DOP)

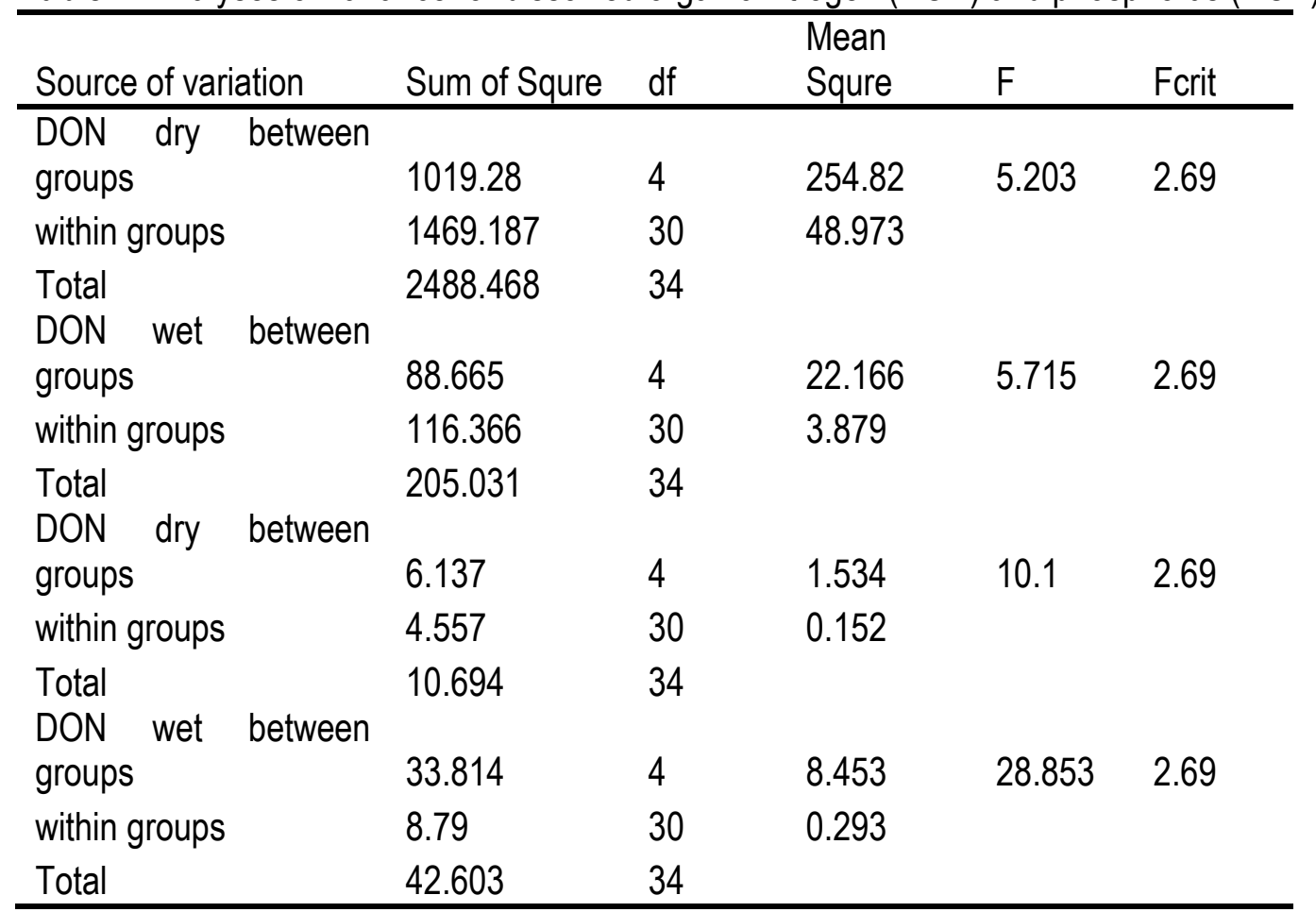

Results from analysis of variance Table 2, show a significant difference $(p<0.05)$ among the DOP concentration from the various sites.

The DOP content of all the samples in the study were greater than the permissible limit of $0.03 \mathrm{mg} / \mathrm{l}$ defined by WHO (2011). The Tukey test (Table 3), indicates that there was a significant difference between sites Nguru \& Baturiya, Nguru \& Matara-Uku, Nguru \& Lokoja, Jebba \& Baturiya, Jebba \& Matara-Uku and Jebba \& Lokoja during the wet season.

Table 3: Tukey HSD posthoc test for dissolved organic phosphorus in wet season for 2015

\begin{tabular}{|c|c|c|c|c|}
\hline \multirow[t]{2}{*}{$\begin{array}{l}\text { Sampling } \\
\text { site }\end{array}$} & \multirow[t]{2}{*}{$\mathrm{N}$} & \multicolumn{3}{|c|}{ Subset for alpha $=0.05$} \\
\hline & & 1 & 2 & 3 \\
\hline Nguru & 7 & 3.6500 & & \\
\hline Jebba & 7 & 3.6971 & & \\
\hline $\begin{array}{l}\text { Baturiya } \\
\text { Matara- }\end{array}$ & 7 & & 4.9271 & \\
\hline Uku & 7 & & 5.5486 & 5.5486 \\
\hline Lokoja & 7 & & & 6.1100 \\
\hline Sig. & & 1.0000 & 0.227 & 0.319 \\
\hline
\end{tabular}

Table 3, revealed that the DOP concentrations in Nguru and Jebba were significantly lower than those recorded in Baturiya, Matara-Uku and Llokoja. while the DOP concentration in Matara-Uku and Lokoja wetlands show no significant variation. The mean concentration of DOP (Figure 2), decreases in the following sequence during the wet season, Lokoja>> Matara-Uku>Baturiya $>$ Jebba $>$ Nguru. The extensive use of organophosphorus insecticides and wastewaters from residential homes entering into the wetlands during the wet season may have led to the high DOP concentration observed in the wet season.

Table 4, shows DOP concentrations in wetland ponds during the dry season of 2015. The concentrations obtained were in the range of $1.25 \pm 0.001-3.78 \pm 0.001 \mathrm{mg} / \mathrm{l}$. Highest level was observed at site M6 in lokoja (3.78 \pm 0.001 $\mathrm{mg} / \mathrm{l})$ while the lowest value was recorded at site N2 in Nguru wetland during the wet season.

Analysis of variance (Table 2), show that, there is a significant difference $(p<0.05)$ among the DOP concentration from the various sites during the dry season. The Tukey test (Table 5) 
indicate that there was no significant difference between sites Jebba and Nguru, but a significant difference was observed between these two sites and those of Baturiya, MataraUku and Lokoja (Figure 2), during the dry season

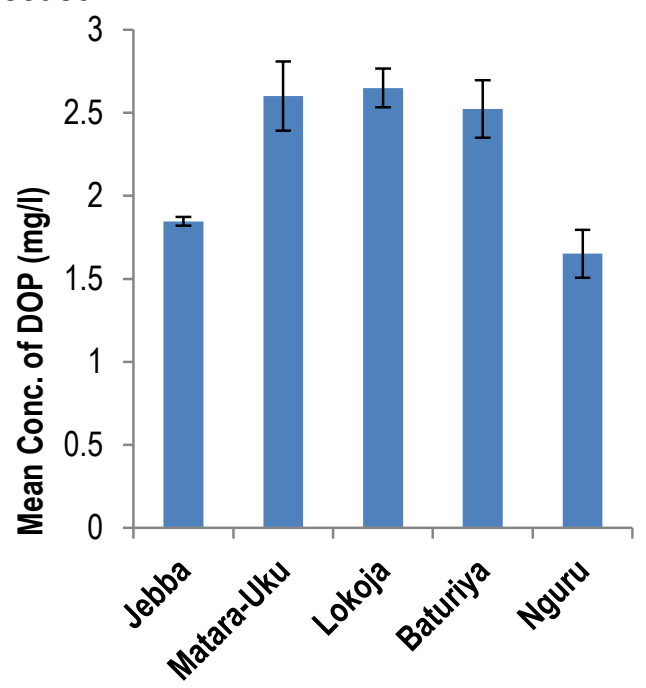

Figure 2: Mean concentrations of dissolved Organic Phosphorus in wetlands during the wet season
Table 5: Tukey HSD posthoc test for dissolved organic phosphorus in dry season for 2015

\begin{tabular}{|c|c|c|c|}
\hline Sampling site & $\mathrm{N}$ & \multicolumn{2}{|c|}{ Subset for alpha $=0.05$} \\
\hline & & 1 & 2 \\
\hline Nguru & 7 & 1.6529 & \\
\hline Jebba & 7 & 1.8471 & \\
\hline Baturiya & 7 & & 2.5229 \\
\hline Matara-Uku & 7 & & 2.6014 \\
\hline Lokoja & 7 & & 2.6500 \\
\hline Sig & & 0.882 & 0.972 \\
\hline
\end{tabular}

Uku>Baturiya $>$ Jebba $>$ Nguru. The low values recorded during the dry season may be due to adsorption of DOP onto clay and precipitation as calcium and aluminium phosphates.

Table 4: Mean Concentration of DOP in Jebba, Baturiya, Lokoja, Matara-Uku and Nguru Wetlands during the Dry Season of 2015

\begin{tabular}{llllll}
\hline Site & Concentration $(\mathrm{mg} / \mathrm{l})$ & Site & Concentration $(\mathrm{mg} / \mathrm{l})$ & site & Concentration $(\mathrm{mg} / \mathrm{l})$ \\
\hline $\mathrm{J} 1$ & $1.96 \pm 0.001$ & LA1 & $2.22 \pm 0.001$ & $\mathrm{~N} 1$ & $1.38 \pm 0.001$ \\
$\mathrm{~J} 2$ & $1.80 \pm 0.002$ & LA2 & $2.42 \pm 0.003$ & $\mathrm{~N} 2$ & $1.25 \pm 0.001$ \\
$\mathrm{~J} 3$ & $1.95 \pm 0.002$ & LA3 & $2.38 \pm 0.003$ & $\mathrm{~N} 3$ & $1.34 \pm 0.001$ \\
$\mathrm{~J} 4$ & $1.80 \pm 0.002$ & LA4 & $3.02 \pm 0.002$ & $\mathrm{~N} 4$ & $1.84 \pm 0.002$ \\
$\mathrm{~J} 5$ & $1.82 \pm 0.001$ & LA5 & $2.97 \pm 0.001$ & $\mathrm{~N} 5$ & $1.47 \pm 0.001$ \\
$\mathrm{~J} 6$ & $1.80 \pm 0.002$ & LA6 & $2.77 \pm 0.002$ & $\mathrm{~N} 6$ & $2.15 \pm 0.001$ \\
$\mathrm{~J} 7$ & $1.80 \pm 0.002$ & LA7 & $2.77 \pm 0.001$ & $\mathrm{~N} 7$ & $2.14 \pm 0.001$ \\
BR1 & $2.07 \pm 0.001$ & M1 & $2.29 \pm 0.002$ & & \\
BR2 & $2.31 \pm 0.001$ & M2 & $2.45 \pm 0.001$ & & \\
BR3 & $2.38 \pm 0.003$ & M3 & $2.77 \pm 0.003$ & & \\
BR4 & $2.29 \pm 0.002$ & M4 & $2.30 \pm 0.002$ & & \\
BR5 & $3.09 \pm 0.002$ & M5 & $2.29 \pm 0.003$ & & \\
BR6 & $3.26 \pm 0.002$ & M6 & $3.78 \pm 0.001$ & & \\
BR7 & $2.260 \pm .001$ & M7 & $2.33 \pm 0.003$ & & \\
\hline
\end{tabular}




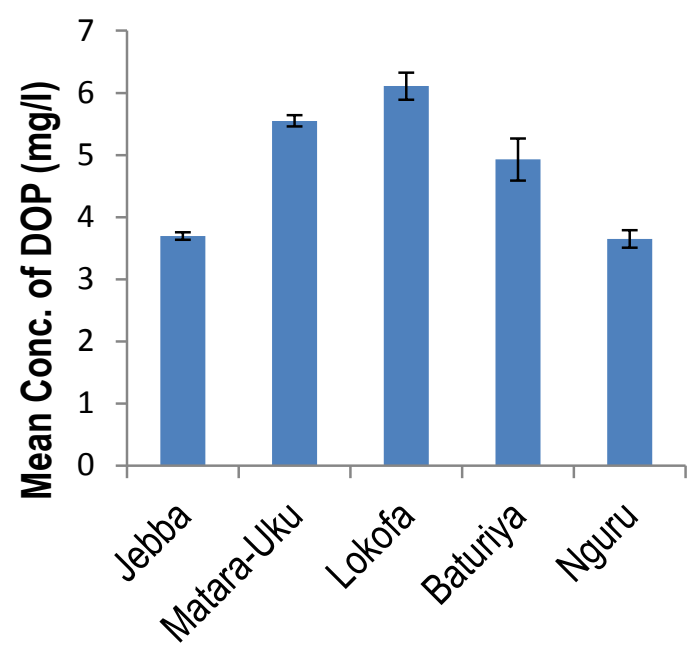

Figure 3: Mean concentrations of dissolved Organic Phosphorus in wetlands during the dry season

Moreover, the t-test result show that there is a significant difference at $p<0.05$, between the DOP concentrations in wet and dry seasons, as the value of the calculated $t(16.99)$ is greater than the critical $t$ value (2.032) two tailed. Pearson correlation also revealed a strong positive correlation of 0.63 , between the DOP concentrations at 0.05 (2-tailed) in the wet and dry seasons of 2015 .

The dissolved organic phosphorus (DOP), concentrations in surface water collected from central Baltic ranged from 0.20 to $0.31 \mathrm{mg} / \mathrm{l}$ (Monika and Günther, 2007), which is lower than the values recorded in all sites analysed in this study. This may be attributed to the runoff from farm lands around these wetlands as well as the use of organic refuse wastes from dumping sites as a source of manure. It has been reported in UK that agricultural lands contribute about $28 \%$ of the phosphorus load in water bodies (Hunt et al., 2004; White and Hammond, 2007). Similarly, Wei et al., (2013) reported an averaged value of $0.021 \pm 0.003$ for the total phosphorus in surface water. However, this value is far more less than the values recorded in this study, which may be associated with the use of waste treatment plant in this area. Nguru wetlands which have the lowest DOP, concentrations among the wetlands studied, may be attributed to increase in photosynthetic activity of algae and other aquatic vegetations, which lower the levels of dissolved carbon (IV) oxide, $\mathrm{CO}_{2}$, in the water resulting to high pH levels. Diaz et al., (1995), also reported that high $\mathrm{pH}$ values associated with high calcium levels can potentially, precipitate phosphorus as calcium-phosphate minerals.In addition, the DOP levels in sites LA2, M2 and BR2 in the wet seasons were significantly higher than those recorded for sites $\mathrm{J} 2$ and N2. A survey of the wetlands revealed that, these locations experience intensive farming activities as well as runoff from residential homes. Generally, the DOP concentrations were higher in the wet season than in the dry season, possibly due to run off run agricultural lands and input from domestic waste.

Table 6 shows DON concentrations in wetland ponds during the wet season of 2015. The concentrations recorded were in the range of $6.79 \pm 0.11-17.1 \pm 0.22 \mathrm{mg} / \mathrm{l}$. Highest level was observed at site $\mathrm{J} 2$ in Jebba $(17.1 \pm 0.22 \mathrm{mg} / \mathrm{L})$, while the lowest value was recorded at site BR2 in Baturiya wetland during the wet season.

Also, Table 2, shows that there is a significant difference $\quad(p<0.05)$ among the DON concentration from the various sites. The DON content of all the samples in the study were greater than the permissible limit of $1.0 \mathrm{mg} / \mathrm{l}$ defined by WHO (2011). From the posthoc test (Table 7), significant difference was recorded between sites Baturiya and Jebba, Lokoja and Jebba, during the wet season, as the difference between their mean concentrations is greater than the list Significant Difference (LSD) value. But no significant difference was recorded between Nguru and Jebba and Matara-Uku and Jebba.

Table 8 shows the DON concentrations in wetland ponds during the dry season of 2015. The concentrations recorded were in the range of $4.00 \pm 0.002-37.2 \pm 0.021 \mathrm{mg} / \mathrm{l}$. Highest level was observed at site BR5 in Baturiya $(37.2 \pm 0.021 \mathrm{mg} / \mathrm{l})$ while the lowest value was recorded at site N3 in Nguru wetland during the dry season. 
Table 6: Mean Concentration of DON in Jebba, Baturiya, Lokoja, Matara-Uku and Nguru Wetlands during the Wet Season of 2015

\begin{tabular}{llllll}
\hline Site & Concentration $(\mathrm{mg} / \mathrm{l})$ & site & Concentration $(\mathrm{mg} / \mathrm{l})$ & site & Concentration $(\mathrm{mg} / \mathrm{l})$ \\
\hline $\mathrm{J} 1$ & $14.4 \pm 0.32$ & LA1 & $10.9 \pm 0.11$ & $\mathrm{~N} 1$ & $11.9 \pm 0.05$ \\
$\mathrm{~J} 2$ & $17.1 \pm 0.22$ & LA2 & $10.3 \pm 0.22$ & $\mathrm{~N} 2$ & $11.8 \pm 0.11$ \\
$\mathrm{~J} 3$ & $14.1 \pm 0.31$ & LA3 & $7.50 \pm 0.12$ & $\mathrm{~N} 3$ & $7.18 \pm 0.10$ \\
$\mathrm{~J} 4$ & $13.6 \pm 0.11$ & LA4 & $11.7 \pm 0.09$ & $\mathrm{~N} 4$ & $10.9 \pm 0.12$ \\
$\mathrm{~J} 5$ & $10.8 \pm 0.12$ & LA5 & $9.55 \pm 0.02$ & $\mathrm{~N} 5$ & $12.1 \pm 0.11$ \\
$\mathrm{~J} 6$ & $14.8 \pm 0.21$ & LA6 & $8.53 \pm 0.11$ & $\mathrm{~N} 6$ & $12.0 \pm 0.09$ \\
$\mathrm{~J} 7$ & $12.4 \pm 0.17$ & LA7 & $8.68 \pm 0.12$ & $\mathrm{~N} 7$ & $11.9 \pm 0.22$ \\
BR1 & $11.3 \pm 0.02$ & M1 & $9.16 \pm 0.11$ & & \\
BR2 & $6.79 \pm 0.11$ & M2 & $11.3 \pm 0.11$ & & \\
BR3 & $7.74 \pm 0.13$ & M3 & $15.2 \pm 0.12$ & & \\
BR4 & $10.7 \pm 0.12$ & M4 & $13.5 \pm 0.10$ & & \\
BR5 & $11.6 \pm 0.12$ & M5 & $11.3 \pm 0.11$ & & \\
BR6 & $9.47 \pm 0.11$ & M6 & $11.0 \pm 0.21$ & & \\
BR7 & $8.76 \pm 0.11$ & M7 & $7.26 \pm 0.07$ & & \\
\hline
\end{tabular}

Table 7: Tukey HSD posthoc test for dissolved organic nitrogen in wet season for 2015

\begin{tabular}{cccc}
\hline Sampling site & $\mathrm{N}$ & \multicolumn{2}{c}{ Subset for alpha $=0.05$} \\
\hline & \multicolumn{2}{c}{1} \\
Baturiya & 7 & 9.4800 & \\
Lokoja & 7 & 9.5943 & \\
Nguru & 7 & 11.1114 & 11.1114 \\
Matara-Uku & 7 & 11.2457 & 11.2457 \\
Jebba & 7 & & 13.8857 \\
Sig & & 0.462 & 0.089 \\
\hline
\end{tabular}

Table 8: Mean Concentration of DON in Jebba, Baturiya, Lokoja, Matara-Uku and Nguru Wetlands during the Dry Season of 2015

\begin{tabular}{llllll}
\hline site & Concentration $(\mathrm{mg} / \mathrm{l})$ & site & Concentration $(\mathrm{mg} / \mathrm{l})$ & site & Concentration $(\mathrm{mg} / \mathrm{l})$ \\
\hline $\mathrm{J} 1$ & $17.2 \pm 0.062$ & LA1 & $21.9 \pm 0.012$ & $\mathrm{~N} 1$ & $8.53 \pm 0.003$ \\
$\mathrm{~J} 2$ & $16.1 \pm 0.002$ & LA2 & $17.8 \pm 0.002$ & $\mathrm{~N} 2$ & $9.00 \pm 0.120$ \\
$\mathrm{~J} 3$ & $10.7 \pm 0.011$ & LA3 & $30.6 \pm 0.240$ & $\mathrm{~N} 3$ & $4.00 \pm 0.002$ \\
$\mathrm{~J} 4$ & $18.2 \pm 0.101$ & LA4 & $16.4 \pm 0.024$ & $\mathrm{~N} 4$ & $7.341 \pm 0.022$ \\
$\mathrm{~J} 5$ & $9.55 \pm 0.004$ & LA5 & $19.2 \pm 0.110$ & $\mathrm{~N} 5$ & $6.08 \pm 0.002$ \\
$\mathrm{~J} 6$ & $9.55 \pm 0.220$ & LA6 & $24.2 \pm 0.210$ & $\mathrm{~N} 6$ & $4.50 \pm 0.003$ \\
$\mathrm{~J} 7$ & $17.2 \pm 0.085$ & LA7 & $17.2 \pm 0.003$ & $\mathrm{~N} 7$ & $10.5 \pm 0.002$ \\
BR1 & $30.2 \pm 0.100$ & $\mathrm{M} 1$ & $9.48 \pm 0.032$ & & \\
BR2 & $18.2 \pm 0.120$ & $\mathrm{M} 2$ & $11.5 \pm 0.033$ & & \\
BR3 & $1.53 \pm 0.002$ & $\mathrm{M} 3$ & $15.2 \pm 0.100$ & & \\
BR4 & $34.9 \pm 0.140$ & $\mathrm{M} 4$ & $16.9 \pm 0.064$ & & \\
BR5 & $37.2 \pm 0.021$ & $\mathrm{M} 5$ & $17.9 \pm 0.002$ & & \\
BR6 & $7.19 \pm 0.003$ & $\mathrm{M} 6$ & $15.0 \pm 0.103$ & & \\
BR7 & $23.3 \pm 0.120$ & $\mathrm{M} 7$ & $9.71 \pm 0.120$ & & \\
\hline
\end{tabular}


The Tukey test (Table 9), indicate that the mean DON concentration in site Nguru is significantly lower than those recorded in Lokoja and Baturiya during the dry season.

Table 9: Tukey HSD posthoc test for dissolved organic nitrogen in dry season for 2015

\begin{tabular}{lclc} 
Sampling site & N & \multicolumn{2}{l}{ Subset for alpha $=0.05$} \\
Nguru & & 1 & 2 \\
Nguru & 7 & 7.1357 & \\
Matara-Uku & 7 & 13.6700 & 13.6700 \\
Jebba & 7 & 14.07143 & 14.0714 \\
Lokoja & 7 & & 21.0429 \\
Baturiya & 7 & & 21.7886 \\
Sig & & 0.363 & 0.218
\end{tabular}

The difference between the levels of DON in sites Nguru and Matara-Uku, Nguru and Jebba were 6.52 and 6.94 respectively, which were lower than the LSD value, indicating that the levels of DON in the two sites do not differ significantly. However, the DON concentrations in Jebba wetlands are lower than those recoded in Baturiya. The high level of DON recorded was attributed to the use of nitrogenbased fertilizers and the inflow of wastewater into the wetlands from residential homes.

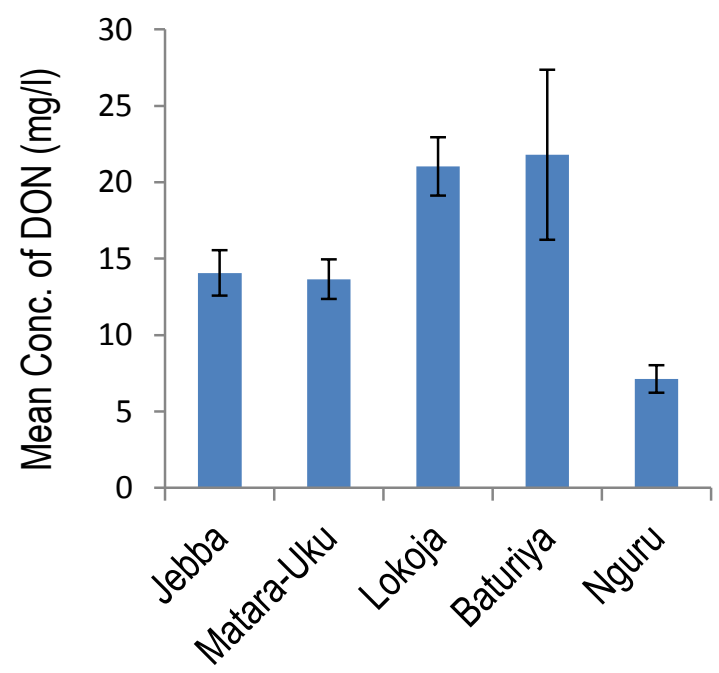

Figure 4: Mean concentrations of dissolved Organic Nitrogen in wetlands during the wet Season

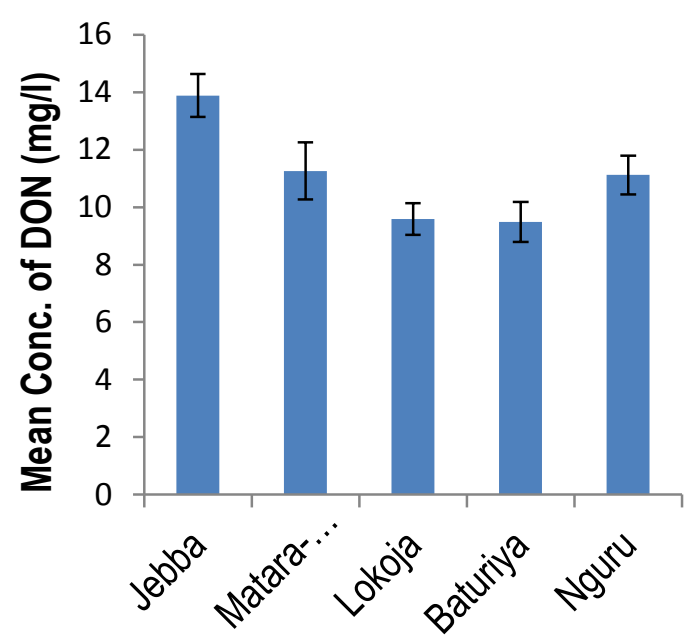

Figure 5: Mean concentrations of dissolved Organic Nitrogen in wetlands during the dry Season

Residential buildings are also around the Lokoja, Matara-Uku and Baturiya wetlands and could also impact the nitrate levels and cause them to rise. The t-test analysis at $p<0.05$, shows that there is no significant difference between the concentrations of DON in wet and dry seasons.

The significantly high DON concentrations observed in Figures 4 and 5, in Baturiya, Matara-Uku and Lokoja wetlands compared with the rest of the wetland sites, could have been caused by runoff from agricultural farms.

Moreover, DON concentrations from the Ipswich River and 38 catchments ranged from 170 to $825 \mathrm{mg} / \mathrm{l}$ (Brian et al., 2004), which is extremely higher than the values recorded in this study. This very high DON concentration in the Ipswish River was attributed to the discharge of sewage effluent into the river. Furthermore, all of the DON concentrations in this study are at the upper end of reported range by Bronk, (2002) and Homewood, et al., (2004) for estuary $(0.315 \pm 0.24 \mathrm{mg} / \mathrm{l})$ and rivers $(0.456 \pm 0.29 \mathrm{mg} / \mathrm{l})$ in UK. Also, Binet al., (2011), reported an average of $0.34 \mathrm{mg} / \mathrm{l}$ for DON in water, which is much less than the values obtained in this study.Kennedy, et al. 2004 recorded average of $14.07 \mathrm{mg} / \mathrm{l} \mathrm{NO} 3^{-}$in Northern Britainwetland surface and soilwaterwhich is in agreement with the values 
observed in this study. Whereas, DON concentrations obtained in boxford mash riparian wetland on river lambourin in Southern England ranged from 2.0 to $4.0 \mathrm{mg} / \mathrm{l}$ (Prior and Johnes, 2002), which was lower than the values recorded in this study. It has been observed that agricultural lands contribute 70 $\%$ of the nitrogen load to UK water bodies (Hunt et al., 2004; White and hammonnd, 2007). The major activity in the sampling area is farming, which involved the use of inorganic and organic fertilizers. This may have contributed to the high levels of DON recorded. The relatively low DON concentrations obtained in Nguru wetlands may be attributed to bacterial ammonification of DON to ammonium and nitrate (Kerner and Spitzy, 2001). They also reported that in Elbe estuary about $65-86 \%$ of the DON was converted to nitrate.

The marked variation in the volume of wetland ponds in the different sites coupled with the long hydroperiod observed in Nguru wetlands, may have also contributed to the relatively low DON and DOP recorded in this area.

There is no systematic trend in DOP and DON concentrations as one move from one sampling site to the other in each of the location (Tables $1,4,6$ and 8 ). These wetlands receive run off from farm lands in all directions and observed similar hydroperiod which may have led to the observed similarity in DOP and DON levels in each wetland location.

Figures 2, 3, 4 and 5 revealed that the concentrations of DOP were much lower than those of DON in both the wet and the dry seasons. Since, phosphates and nitrates are considered nutrients for organisms such as algae and even though both compounds are found at high levels in the wetlands samples, phosphorus appear to be the limiting factor. This results in the use up of phosphate content of the samples in comparison with nitrate levels. From the differences in these nutrients dynamics between the wet and dry seasons, it could be suggested that fertilizers, organophosphoric insecticides and run off are the major source of DON and DOP in these wetlands (Alex, et al., 2012).

\section{CONCLUSION}

Seasonal dynamics of DON and DOP concentrations were identified in different sites of the wetlands. The DOP concentration was 218 times greater than the recommended value at the upper limit and 42 fold greater than the recommended value at the lower limit. While that of DON is 37.2 times higher than the permissible limit at the upper limit and The results from the analysis revealed that the wetlands contained high concentrations of nitrogenous and phosphorus compounds.

\section{REFERENCES}

Alex, T. C., Jianing, D., William, H. C., Daniel, R. H. And Jun-Jian W.(2012). Dissolved organic matter and nutrient dynamics of a coastal freshwater forested wetland in Winyah Bay, South Carolina.

APHA, American Public Health Association, (1992). Standard Methods for Water and Effluent Analysis. 18 $18^{\text {th }}$ edition. American Public Health Association, Washington DC.

Bin, X., Tao, Y., Da-Peng, L., Chen-Yan, H., YiLi, L., Sheng-Ji, X., Fu-Xiang, T., NaiYun, G. (2011). Measurement of dissolved organic nitrogen in a drinking water treatment plant: Size fraction, fate, and relation to water quality parameters

Brian, A., Pellerin 1., Wilfred, M. W., Charles S. H., William H. M., Michael R. W., Charles J. V., Michelle L. D. (2004). Role of Wetlands and Developed Land Use on Dissolved Organic Nitrogen Concentrations and DON/TDN in Northeastern U.S. Rivers and Streams. American Society of Limnology and Oceanography, Inc, Limnol. Oceanogr, 49(4): 910-918.

Bronk, D. A.(2002). Dynamics of DON. In: Hansell, D.A., Carlson, C.A. (Eds.), Biogeochemistry of Marine Dissolved Organic Matter. Academic Press,

Charles, J. P. and Jennifer R. K. (2003). Methods of Analysis by the U.S. Geological Survey National Water 
Quality Laboratory: Evaluation of Alkaline Persulphate Digestion as an Alternative to Kjeldahl Digestion for Determination of Total and Dissolved Nitrogen and Phosphorus in Water. Pp $1-40$

Diaz, O.A., Reddy,K.R. and Moore, P.A. (1995). Solubility of inorganic $P$ in stream water as influenced by $\mathrm{pH}$ and Ca concentration. Water Res. (in press).

Harrison, J. ASeitzinger, ., S. P., Bouwman, A. F., Caraco, N. F., Beusen, A. H. W. and Vo"ro"smarty, C. J. (2005). Dissolved inorganic phosphorus export to the coastal zone: Results from a spatially explicit, global model, Global Biogeochem. Cycles, 19, GB4S03.

Hollis, G.E., Adams, W. M. and Aminu, K. M. (1993). Wetland and conservation, The Hadejia-Nguru wetlands: Environment, Economy and Sustainable Development of a Sahelian Flood Plain Wetland. Brothers Press Limited, Norwitch, U.K. 28-244

Homewood, J.M., Purdie, D. A. and Shaw, P. J.(2004). Influence of sewage inputs and fish farm effluents on dissolved nitrogen species in a chalk river. Water Air Soil Pollution Focus, 4, 117-125.

Hunt, D.T.E., Dee, A.S., Oakes, D. B. (2004). Updating an estimate of the sources of nitrogen to UK waters - Phase 2. Defra Final Report for Project WT03016. <http://www.defra.gov.uk/science/project data/DocumentLibrary/WT0701CSF/W T03016_1573.FRA.pdf>.

Johnes P. J. and Heathwaite, A. L. (1992). A procedure for the simultaneous Determination of total nitrogen and total phosphorus in freshwater samples using persulphate microwave digestion. Water Research, 26(10): 1287-1992.

Johnston, C.A. (1991). Sediment and nutrient retention by freshwater wetlands: effects on surface water quality. Critical Reviews in Environmental Control, 21:491-565.

Kennedy, M.P. and Murphy K.J. (2004). Indicator of nitrate in wetland surface and soil- water: interaction of vegetation and environmental factors. Hydrology and earth system science, 8(4): 663-672.

Kennedy, M.P.(2001). Predicting the impact of hydrological change on wetland vegetation. $\mathrm{PhD}$ thesis, University of Glasgow, U.K.

Kerner, M., Spitzy, A.(2001). Nitrate regeneration coupled to degradation of different size fractions of DON by the picoplankton in the Elbe estuary. Microbial Ecology, 41, 69-81.

Leenheer, J. A. (2004). Comprehensive assessment of precursors, diagenesis, and reactivity to water treatment of dissolved and colloidal organic matter. Water Science and Technology, 4:1-9.

Mitsch, W.J. and Gosselink, J.G. (1993). Wetlands. Van Nostrand Reinhold, New York.

Monika, N. and Günther, N. (2007). Bioavailable dissolved organic phosphorus and phosphorus use by heterotrophic bacteria. Aquatic Biology, 1: 151-160.

Nikolaos, M. T., George, A. Z., Aristidis, N. A. and John, A. S. (2010). A new approach to indophenol blue method for determination of ammonium in geothermal waters with high mineral content, Internernational Journal of Environmental Analytical Chemistry, 90(2): 115-126.

Peat, D.M.W., McKelvie, I.D., Matthews, G.P., Haygarth, P.M., and Worsfold, P.J. (1997). Rapid determination of dissolved organic phosphorus in soil leachates and runoff waters by flow injection analysis with on-line photo-oxidation. Talanta 45: 47-55

Pitta1, E.,Zeri1, C. Tzortziou, M. Dimitriou, E. Paraskevopoulou, V. Dassenakis, E. Scoullos, M. and Anagnostou, E. (2014). Dissolved organic matter cycling in eastern Mediterranean rivers experiencing multiple pressures. The case of the trans-boundary Evros River. Mediterranean Marine Science Mediterranean Marine Science, 15(2): 398-415. 
Prior H. and Johnes P. (2002). Regulation of surface water quality in a Cretaceous Chalk catchment, UK: an assessment of the relative importance of in stream and wetland processes. The Science of the Total Environment, 282:159-174.

Ramsar, C. (1994). Convention on Wetlands of International Importance Especially as Waterfowl Habitat, The Convention on Wetlands text, as amended in 1982 and 1987, ; United Nations Educational, Scientific and Cultural Organization (UNESCO): Paris, France.

Reddy, K.R., Kadlec, R.H., Flaig, E. and Gale, P.M. (1999). Phosphorus retention in streams and wetlands: A review. Critical Reviews in Environmental Science and Technology, 29(1): 83-146.

Walbridge, M.R. and Struthers J. P. (1993). Phosphorus retention in non-tidal palustrine forssted wetlands of the midatlantic region. Wetlands, 13(2), 84-94
Wei, L.,TeCaoa, L., Xiaolin Z., Guorong, Z. and Ping, X. (2013). Effects of water depth on carbon, nitrogen and phosphorus stoichiometry of five submersed macrophytes in an insitu experiment, Ecological Engineering, 61:358-365

Westerhoff, P. and Mash, H. (2002). Dissolved organic nitrogen in drinking water supplies: a review. J Water Supply: Res Technol., 51:415-48.

White, P.J., Hammond, J. P.(2007). Updating the estimate of the sources of phosphorus in UK waters. Defra Final Report for Project WT0701CSF.<http://www.defra.gov.uk/s cience/project_data/DocumentLibrary/W T0701CSF/WT0701CSF4159.FRP.pdf>.

WHO, (2011). Guidelines for Drinking-water Quality. (fourth ed.), World Health Organisation (WHO). 